\title{
Economic Law in Dealing with the Covid 19 Pandemic Crisis
}

\author{
Luhung Kushonggo ${ }^{1}$, Faisal Santiago ${ }^{2}$ \\ \{luhungkushonggo@gmail.com¹, faisalsantiago@borobudur.ac.id²\} \\ Universitas Borobudur, Jakarta, Indonesia ${ }^{1,2}$
}

\begin{abstract}
This article examines the economic law applies in Indonesia, especially concerning dealing with the Covid 19 Pandemic crisis. The global urgency caused by the Covid 19 Pandemic demands an appropriate response in determining economic policies and laws. Through the normative juridical method using literature studies as data collection, it was found that the economic law enacted by the Indonesian government has taken into account the national interest, which means taking a role in the realization of a strong, resilient, and independent national economy based on people and kinship.
\end{abstract}

Keywords: Economic Law; Crisis; Covid 19 Pandemic; Resilient

\section{Introduction}

Law expected to manage public activity in all parts of life, both in public activity, political life, culture, training perspectives, and what is very significant is its capacity and job in directing monetary exercises. The law is required in this monetary movement in light of restricted financial assets from one viewpoint, and limitless interest or need for financial assets then again so that struggles between compatriot in battling about these business assets will frequently happen. Nonetheless, in view of the experience of humans themselves, the role of the law must be measurable so that it does not turn off the initiative and human creativity which is the main driving force in economic development.

All changes occurred in society are not possible if humans do not have the opportunity and breadth to think and be creative. Therefore, various forms of rules are needed that regulate how humans can carry out their activities safely, not interfering with each other or even destroying each other so that opportunities to develop knowledge are hampered. Thus, a legal role is needed to secure, control and plan monetary life with the goal that the elements of financial action can be coordinated towards progress and thriving for the entire local area. The law can't just restrict and stifle yet additionally gives openings and even urges individuals to find different developments that can drive the monetary exercises of a country.

As it has known that jurisprudence is a science that is included in the practical knowledge group by occupying a special position in the science classification because of its nature as a normative knowledge that contains its characteristics. The object of the study is also related to the demand to behave in a certain way whose compliance does not completely depend on the person's free will but the public power can force it.[1] The role of law in the economic development of a nation is something that cannot be ignored. It is very plain that the legal 
conditions of nationality are efficient, then economic improvement will be easy to implement. On the other hand, if the law cannot play an efficacious role, it will certainly harm economic development.

The economic impact of COVID-19 is more complicated than the global economic crisis of 2008-2009 that was felt by world leaders and decision-makers in the business sector.[2] The assumption is that the economic impact of the Covid-19 pandemic is in the form of shocks due to absent supply conditions. Two conditions cause this shock. First, workers in the manufacturing sector were exposed to the virus that they stopped working, automatically reducing production capacity. As emphasized, if 10 percent of the earth's population is infected it can result in serious labor shortages that will affect the economic and financial infrastructure of a country. Second, the population activities are limited to suppress the spread, but at the same time have an impact on reducing production, decreasing international trade, the creative economy, tourism, and other economic activities.

The Indonesian government responded quickly to deal with the situation. At the beginning of the pandemic, the Ministry of Finance took several concrete steps to reduce the negative socio-economic impacts, including by releasing several state financial management policy packages in the form of tax incentives, labor, export-import, finance, and industry to help the business world to survive.[3] However, the core policies adopted by the government and expected to save the national economy from the brink of crisis have not been able to overcome the decline in various macroeconomic indicators and business bankruptcies in the real sector at the micro, small, medium, and large scales. The increasing escalation of the pandemic and reaching remote areas is becoming a distinct difficulty for the economic recovery that is being pursued. The global crisis caused by the COVID-19 pandemic demands an appropriate response in determining economic policies and laws. This article examines the economic law that applies in Indonesia, especially concerning the Covid-19 pandemic crisis.

\section{Method}

Methodologically, this research uses a normative juridical approach, namely an approach that is performed through the applicable laws and regulations.[4] The method is applied in legal research on various business law instruments related to the research object. The specifications of this research are descriptive analysis, meaning that this research is not only limited to an activity to collect and compile or explain primary legal materials, secondary legal materials and tertiary legal materials only, but also analyze them related to legal theories and implementation practices of positive law concerning problems (objects of research).[5] All secondary data that has been collected will be analyzed in a qualitative normative manner using a legal research approach that has been determined to examine and find answers to legal problems in this study, which are then outlined in the form of descriptive research results.

\section{Discussion}

Covid-19 as a health problem then transitions into a social and economic matter in a speedy tempo. Referring to the July 2020 World Bank's Indonesian Economic Prospect Edition report, which is named "The long road to recovery," Indonesia's economic performance this year only grew by zero percent. However, there is a second, worse scenario where the Indonesian economy experiences a contraction of -2 percent (minus two percent) is 
influenced by the external environment in the form of a worse global recession plus more stringent Large-Scale Social Restrictions (PSBB) factors in the nation's capital and many areas that directly affect the gross domestic product. Efforts to restore the economy will be hampered by the pandemic wave that has not yet ended.

The government's strategic response through the formulation of the legal basis for policies is considered very appropriate to provide guarantees for decision-making actors so as not to experience lawsuits outside the context of the discretion of government officials (traumatic policy users in the case of Century Bank). The publication of Covid-19 handling policies new regulations will provide legal certainty for executives in working full of these risks. Under high pressure, there is an urgent need for restructuring by reformatting the state budget posture that is adaptive to the economic turbulence impacted by the pandemic.

Significant pressures on the spending side have prompted a Revised State Budget in accordance with the inexorably earnest public need to address general wellbeing catastrophes, grow social security nets by underlining value and flawless. The survey of the construction of the State Budget is helped out through the specification of Presidential Regulation Number 54 of 2020 and afterward again corrected by the issuance of Presidential Regulation Number 72 of 2020 .

The accumulation of the spread of the Covid-19 pandemic directly put majestic pressure on the regional and central economies shown in table 1, the economic growth of Quarter I2020. Based on the unpredictable situation, Bank Indonesia (2020) set a projection of Indonesia's economic growth of 4.2 to 4.6 percent with a higher ratio than the projections of the $\mathrm{ADB}$ and the IMF, where the ADB projected an increase of 2.5 percent, while the IMF gave a pessimistic forecast with an estimate of 0.5 percent.[6]

Amid the global crisis caused by the 1998 global crisis, the Government of Indonesia has issued three Government Regulations instead of laws (Perppu). First, Perppu Number 2 of 2008 concerning the Second Amendment to Law Number 23 of 1999 concerning Bank Indonesia. The purpose of this Perppu is to help banks experiencing liquidity difficulties by applying to Bank Indonesia to obtain a Short Term Funding Facility (FPJP). The requirements for obtaining an FPJP were initially high maintenance, making it difficult for banks to fulfill during a crisis.

In addition, there is Perppu Number 3 of 2008 concerning Amendments to Law Number 24 of 2004 concerning the Deposit Insurance Corporation (LPS). This regulation aims to increase public confidence in the banking industry by increasing the number of customer deposits guaranteed by LPS. Third, Perppu Number 4 of 2008 concerning the Financial System Safety Net. The goal is that banks and non-bank financial institutions that have a systemic impact can obtain assistance from the government if they experience financial difficulties. The first two of the three Perppu were approved by the House of Representatives into law.

The lesson learned from the financial crisis is that the government must strictly regulate the financial industry. The theoretical questions are how strict and what are the regulatory requirements for the financial management, what are the forms of regulation, what are the regulatory principles, and what should be included in the policies/regulations that underlie the provisions to be issued so that a balance can be achieved between the development of the financial industry, financial system stability, and at the same time consumer protection. The paradigm was used when issuing the Law on the Financial Services Authority.

During the crisis caused by the Covid 19 Pandemic, the experience of the monetary crisis in 1998 became very valuable in determining policies in economic law. Today's fast-paced pattern of economic development has led to the formation of an even distribution of people's 
welfare being the primary goal. It is necessary to have a legal role that influences to compile the new life order to achieve the goal. In subsequent developments, attention is no longer directed to the cultivation of the law but is more related to social changes. The law is no longer seen as a recorder of habits that have formed in the fields of people's lives, but also hoped that the law can be the right revealer of new forces that require the formation of community welfare. As a result, almost all aspects of our lives encounter legal regulations. On the one hand, the law is concerned with the results that will be obtained through its stipulation, and therefore must understand the intricacies of the problems it will regulate. Meanwhile, on the other hand, the law must also be aware that factors and forces outside the law will also influence the law and its working process. So that in formulating legal policies, it is necessary to consider, among other things, psychological factors, sociological factors, and geographical locations.

In a crisis due to the Covid 19 pandemic, the section of interest in a non-industrial nation, particularly Indonesia, is one of the main jobs in prodding financial turn of events. Since in non-industrial countries, that requirement for expanded advancement capital, has consistently been a significant issue in monetary improvement so that among non-industrial nations the worry for financial backers isn't just rich normal assets, yet the main thing is the way to put resources into the country. It can give legitimate sureness and business conviction.

That is the place where the law is a urgent component concerning the legitimate insurance gave by a country to speculation exercises. As expressed by Erman Rajagukguk, that the fundamental variable for the law to have the option to assume a part in financial advancement is whether the law can make "solidness," "consistency," and "decency."[7] The initial two are essentials for any financial framework to work. Remembered for the strength work is the lawful potential to adjust and oblige contending interests. The requirement for a legitimate assignment that can anticipate (consistency) the results of a stage taken is particularly huge for a nation where most of its kin go into financial relations past the conventional social climate interestingly. Parts of reasonableness, like equivalent treatment and normalized examples of government conduct, are important to keep up with market instruments and forestall inordinate administration. So that through a general set of laws and lawful guidelines that can give insurance, it will make assurance (consistency), reasonableness, and productivity for financial backers to contribute their capital.

According to Dhaniswara K. Harjono,[8] concerning this matter and to improve and establish a good speculation environment and in accordance with the bearing and strategies of public turn of events, the means that have been taken are :

a. simplify the cycle and methodology for authorizing and endorsement with regards to speculation;

b. wide open fields that were previously closed or restricted to foreign investment;

c. provide various incentives, both tax, and non-tax;

d. develop regions for speculation with different offices advertised;

e. perfecting distinct legal products by issuing new laws and regulations that better guarantee a healthy investment climate;

f. improve law requirement and question goal processes that are viable and reasonable;

g. perfecting the obligations, capacities, and specialists of the important offices to have the option to offer better types of assistance;

h. opens the chance of unfamiliar offer possession is critical

Specifically, the primary role of economic law during the Covid-19 Pandemic was to provide legal certainty and clarity regarding investment policies while still prioritizing national interests to increase the number and quality of investment which leads to increased 
economic growth, increased employment, increased exports, and foreign exchange earnings, developing technological capabilities, increasing national competitiveness capabilities. In the end, it is hoped that it can improve the welfare of society in general.

\section{Conclusion}

As the world is facing today, the global financial crisis has resulted in the economic legal system in several countries being unable to carry out its functions and roles effectively. It proves that the concept of a liberal economy worldwide cannot be fully and comprehensively applied in Indonesia, especially in the implementation of the formation of legislation in the field of economic law. Therefore, economic values must be explored, such as people's economy, agricultural economy, Pancasila economy, and others are protected by an effective legal system and are fully facilitated and fully supported by the state. Despite the Covid 19 pandemic, escalated monetary incitement complete with financial plan distributions got from different wellsprings of redistribution of focal government uses, reserve funds in-state costs from non-pressing spending plan posts, and capital consumptions that were not focused on and afterward redirected through satisfying wellbeing framework, social security nets, and monetary boost for the business world. Then again, the current spending plan shortfall is unavoidable and anticipated to surpass the greatest edge specified by the law on state accounts.

\section{References}

[1] P. M. Marzuki, An Introduction to Legal Knowledge. Jakarta: Kencana Prenadamedia Group, 2006.

[2] D. S. P. Astuti, “Economy during the Covid-19 Pandemic,” Suara Merdeka, 2020.

[3] A. P. Samosir, " Policy Analysis of Fiscal and Non-Fiscal Incentives on Integrated Economic Development Zones in Eastern Indonesia," http:// www.fiskal.depkeu.go.id/webbkf/link.asp?link=1060000, 2008. .

[4] J. Ibrahim, “ Normative Legal Research Theories and Methods," Bayu Media, Malang, 2006.

[5] M. Abdul Kadir, “Law And Legal Research,” Bandung PT. Citra Aditya Bakti., 2015.

[6] N. S. Engkus, "Covid-19: policies to mitigate the spread and socio-economic impact in Indonesia," Digital Library UIN Sunan Gunung Djati., 2020. .

[7] A. Atkeson, What will be the economic impact of covid-19 in the us? rough estimates of disease scenarios. National Bureau of Economic Research, 2020.

[8] D. K. Harjono, Investment Law. Jakarta: Raja Grafindo Persada, 2007. 